\title{
Brief Communication: Sudden drainage of a subglacial lake beneath the Greenland Ice Sheet
}

\author{
I. M. Howat ${ }^{1}$, C. Porter ${ }^{2}$, M. J. Noh ${ }^{1}$, B. E. Smith ${ }^{3}$, and S. Jeong ${ }^{1}$ \\ ${ }^{1}$ School of Earth Sciences and Byrd Polar Research Center, Ohio State University, Columbus, Ohio, USA \\ ${ }^{2}$ Polar Geospatial Center, University of Minnesota, St. Paul, Minnesota, USA \\ ${ }^{3}$ Polar Science Center, Applied Physics Lab, University of Washington, Seattle, Washington, USA
}

Correspondence to: I. M. Howat (ihowat@gmail.com)

Received: 23 September 2014 - Published in The Cryosphere Discuss.: 16 October 2014

Revised: 17 December 2014 - Accepted: 20 December 2014 - Published: 15 January 2015

\begin{abstract}
We report on the appearance of a $2 \mathrm{~km}$ wide, $70 \mathrm{~m}$ deep circular depression located $50 \mathrm{~km}$ inland of the southwestern margin of the Greenland Ice Sheet that provides the first direct evidence for concentrated, long-term storage, and sudden release, of meltwater at the bed. Drainage of the lake may have been triggered by the recent increase in meltwater runoff. The abundance of such lakes and their potential importance to the ice sheet's hydrologic system and flow regime remain unknown.
\end{abstract}

\section{Introduction}

Recent observations of the Greenland Ice Sheet have revealed a complex hydrological system in which hundreds of gigatonnes of surface meltwater drain toward the margin each summer through both supraglacial and subglacial pathways. The supraglacial drainage system is typified by dendritic river systems and abundant meltwater lakes, ranging up to several kilometers wide. In areas of high accumulation, infiltrating meltwater can also be stored within perennial aquifers deep within the firn (Forster et al., 2014). The supraglacial and subglacial drainage systems are connected through englacial pathways (e.g., moulins) created by hydraulically driven fracturing through $1 \mathrm{~km}$ or more of ice, often facilitated by extensional flow and surface crevassing (Joughin et al., 2013). Meltwater entering the subglacial system disperses rapidly, indicating an efficient drainage system comprised of tunnels extending tens of kilometers into the interior (Chandler et al., 2013; Fitzpatrick et al., 2013).
Supraglacial lakes and firn aquifers store a substantial amount of meltwater, providing a buffer between melting and mass loss to the ocean (Forster et al., 2014; Fitzpatrick et al., 2014). The quantity of perennial subglacial meltwater water storage, however, remains highly uncertain. Thus far, subglacial lakes have only been detected in the far north of the ice sheet (Palmer et al., 2013), where lower snowfall promotes greater geothermal heating of the base and long-term subglacial storage of meltwater. It is not clear whether this water melted from basal ice or reached the bed from the surface. Unlike basally derived meltwater, subglacial storage of surface meltwater would be influenced directly by climate warming and, therefore, is more relevant to understanding ice sheet response to anthropogenic climate change. The high efficiency of Greenland's subglacial drainage system reduces the likelihood that lakes of surface meltwater can form (Palmer et al., 2013). For a hydraulic connection to penetrate to the bed its discharge will likely be high enough to immediately form drainage tunnels and drain toward the margin. While seasonal reductions in drainage system efficiency may lead to slowing or temporary meltwater storage through the winter, this water would likely be flushed from the system the next summer. Finally, the high surface slope of the margin implies a strong hydraulic gradient toward the ice edge that would also prevent lake development.

The most likely location for surface meltwater to be stored subglacially, therefore, would be high in the ablation zone at the uppermost elevation where hydraulic connections to the bed exist. Here, the total supply of melt to the bed would be at a minimum so that the drainage system will be least developed and may not receive input every year. The greater ice thickness and lower surface slope would increase the likelihood that bed relief would cause areas of convergence in 


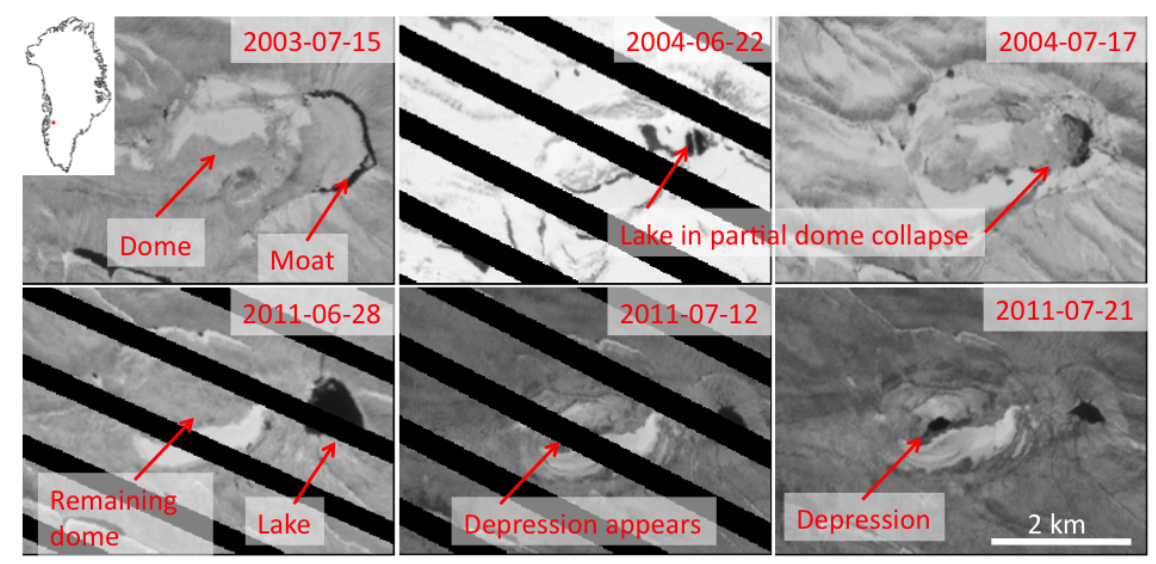

Figure 1. Series of Landsat 7 Enhanced Thematic Mapper Plus panchromatic satellite imagery showing two episodes of the collapse. The 2003 and 2004 images show the formation of a supraglacial lake within a depression on the eastern side of what previously appears to have been a dome edged by a water-filled moat. The 2014 images show the formation of the larger depression within the center of the dome. The black stripes are due to failure of the sensor's scan line corrector system.

the hydraulic potential field. It is in this setting, near the southwest margin of the ice sheet $\left(67.61^{\circ} \mathrm{N}, 48.7^{\circ} \mathrm{W}\right)$, where we identified a prominent depression in the surface, first observable in a Landsat 7 Enhanced Thematic Mapper-Plus (ETM+) satellite image acquired on 12 July 2011 (Fig. 1; see Appendix A for detailed data set descriptions). The feature is not visible on the next earlier image, dated 28 June, indicating that the depression formed in that period. Sub-meter resolution panchromatic imagery and stereoscopic digital elevation models (DEMs) from the WorldView-1 (WV1) satellite of the area were acquired for the first time on 28 October 2011 (Fig. 2). The DEM and accompanying orthoimage reveal an approximately $70 \mathrm{~m}$ deep depression with a diameter of between 1.5 and $2 \mathrm{~km}$ and a total area of $1.6 \mathrm{~km}^{2}$. The walls of the depression have slopes of 10 to $15^{\circ}$. The bottom of the depression is filled with meltwater covering an area of $0.08 \mathrm{~km}^{2}$ that, as the Landsat imagery shows, drained into the depression from a nearby lake. Concentric rings of crevasses that indicate collapse of the surface surround the depression. The northern edge of the depression is bounded by a crevasse over $50 \mathrm{~m}$ wide and more than $30 \mathrm{~m}$ deep.

\section{Observations}

Prior to the 28 October 2011 WV1 acquisition, available elevation data for the area of the depression include (1) an April 1993 overflight by the NASA Airborne Topographic Mapper (ATM) lidar $1 \mathrm{~km}$ east (up-glacier) of the depression, (2) three Ice and Cloud Elevation Satellite (ICESat) laser altimetry passes over the eastern side of the depression acquired in March, June and November 2005 (Fig. 2) and (3) a $40 \mathrm{~m}$ resolution stereoscopic DEM produced from SPOT-5 satellite imagery acquired on 7 July 2008 and distributed by the SPOT 5 stereoscopic survey of Polar Ice:

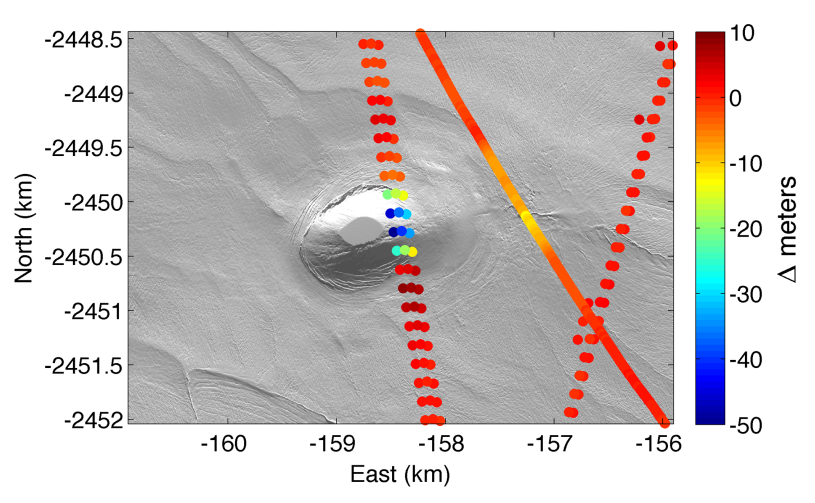

Figure 2. WorldView-1 panchromatic satellite image from 28 October 2011, with (dots) 2005 ICESat-1 and (curve) 1993 Airborne Topographic Mapper lidar tracks overlain. Colors are the difference between the 2011 WorldView DEM and earlier lidar elevations. The November 2005 ICESat track is the westernmost track, running closest to the center of the depression. The map coordinates are in polar stereographic projection with a meridian at $70^{\circ} \mathrm{W}$ (Worlview image (C2011 DigitalGlobe, Inc.).

Reference Images and Topographies (SPIRIT) project (Korona et al., 2009). An additional WV1 DEM was acquired on 5 July 2013. Elevation profiles along the 15 November 2005 ICESat track (Fig. 3) reveal that the depression formed through collapse of what was previously a $5 \mathrm{~m}$ tall dome on the surface fringed by a moat, which was typically filled with snow in the late-summer imagery. The dome lay on a reversed surface slope (i.e., rising to the east in the direction of flow), with a gradient of 0.012 , on the stoss side of a rise (Fig. 3). The down-glacier side of the rise drops twice as steeply to another plateau. Up-glacier of the depression, a small supraglacial lake occupies the base of another 

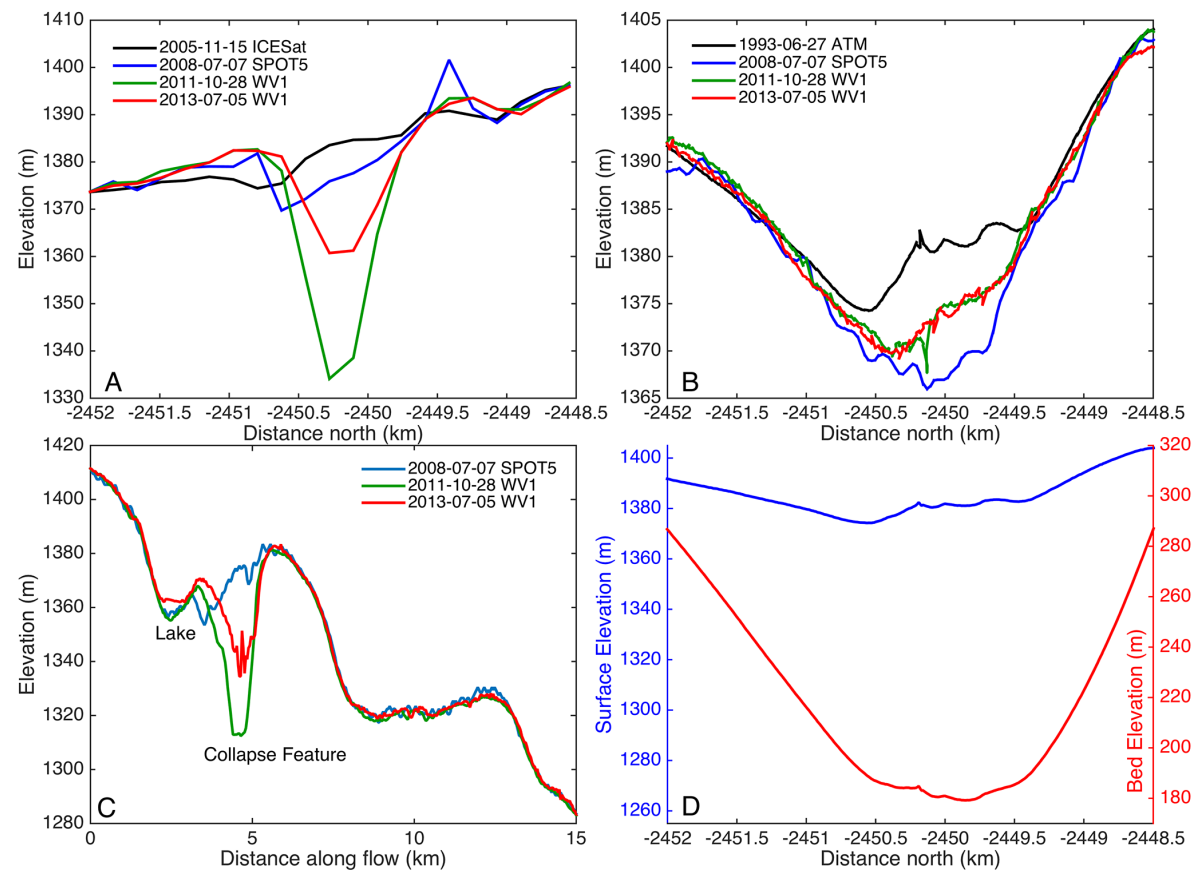

Figure 3. Surface elevations from laser altimetry and stereoscopic digital elevation models along the (a) 15 November 2005 ICESat- 1 and (b) 26 June 1993 ATM tracks shown in Fig. 2. (c) Along-flow (east to west) surface elevation profiles through the center of the depression from three stereoscopic DEMs. (d) Surface (blue) and bed heights (red) for the 1993 airborne survey over the eastern portion of the depression (see Fig. 2). Both vertical axes have the same scale.

steep slope. Such undulating topography is common over the southwestern margin.

Comparison of elevation profiles along the 1993 ATM track (Fig. 3) indicates an earlier lowering of the surface of up to $20 \mathrm{~m}$ prior to the 2008 SPOT DEM over the area immediately upstream of the current depression, at the location where a supraglacial lake has formed intermittently since 2004. An apparent collapse of that surface occurred between the summers of 2003 and 2004 (Fig. 1). Prior to summer 2004, water occupied a narrow moat on the eastern margin of what appeared to be a small dome. In the 15 July 2004 Landsat image, the lake appears in a depression. The surface then rose 5 to $8 \mathrm{~m}$ between 2008 and 2011 (Fig. 3). Inspection of DEM profiles along the flow direction (Fig. 3) reveals that this rising of the surface was due to horizontal advection of a small topographic bump and not infilling.

\section{Discussion}

Based on these data, we conclude that the depression formed due to rapid drainage of a subglacial lake. Drainage occurred in two episodes: a smaller event in 2004 and a larger one in 2011. Prior to the 2004 event, the surface appeared unchanged in imagery extending back to 1972 . This, and the raised surface detected in the 1993 ATM survey, indicates that water storage persisted for at least several decades before drainage. Differencing of the 2008 and 2011 DEMs over the area of the depression gives a minimum total volume change of $2.5 \times 10^{-2} \mathrm{~km}^{3}$. Assuming that vertical displacement of the surface is equal to the depth of the former lake, and that all drainage occurred in the 14 days between the 28 June and 12 July images, gives an average discharge of $20 \mathrm{~m}^{3} \mathrm{~s}^{-1}$. This discharge is similar to that estimated for a supraglacial lake that drained and quickly dispersed into the subglacial drainage system (Das et al., 2008).

Storage of water at the bed requires a flat hydraulic potential surface. This is achieved when the slope of the bed is approximately 11 times steeper than the surface and of opposite sign, so that the force of gravity pulling water along the bed slope balances the gradient in ice overburden. As shown in Fig. 3, the depression occurred on a reversed slope on the stoss side of a rise, with a steeper drop on the lee. A downward step in the bed, such as the down-glacier slope of a subglacial roche moutonnée, would provide the conditions needed for a zero, or reversed, hydraulic gradient. The only available thickness data are from the Kansas University ice-penetrating radar acquired during the same survey as the 1993 ATM flight. These data reveal that the location of the surface depression lies within a shallow bathymetric low, with a maximum ice thickness of $1200 \mathrm{~m}$, into which subglacial water may be routed (Fig. 3). The single transect, however, is not enough to constrain the hydraulic gradient field over the depression. 
Unlike Antarctic subglacial lakes, we assume that this water reached the bed from the surface through moulins and was routed into the lake through the subglacial drainage system. This is suggested by numerous draining surface lakes and moulins visible in the satellite imagery in the vicinity of the depression. Ice flow speeds in this area are only 50 to $60 \mathrm{~m} \mathrm{yr}^{-1}$ (Joughin et al., 2010) indicating little or no generation of basal meltwater due to frictional heating. On the other hand, basal temperatures in the upper ablation zone are likely close to the pressure melting temperature. This, and the continuing influx of heat with surface meltwater, would prevent the subglacial lake from freezing.

The drainage of this subglacial lake, however, may have a similar trigger as the draining and filling of those in Antarctica (Gray et al., 2005; Wingham et al., 2006; Clarke, 2006). Filling of the lake would increase the hydraulic gradient, eventually overcoming the gradient in ice pressure. Drainage would melt channel walls through viscous heat dissipation, enlarging subglacial tunnels and leading to continued drainage despite reduced water pressures. In this case an additional mechanism for triggering drainage may be the transition of the subglacial drainage system from inefficient to efficient modes in the vicinity of the lake. Inefficient systems maintain high water pressures at low subglacial discharges through a network of small cavities. An increase in discharge can cause these cavities to coalesce into efficiently draining tunnels with reduced water pressures (Schoof, 2010). The gradient in water pressure between these modes causes efficient drainage to propagate upstream with increasing water input (Bartholomew et al., 2011). Chemical tracer and ice motion observations at the southwestern Greenland margin suggest efficient drainage up to $50 \mathrm{~km}$ inland, which is also the distance of this lake to the ice sheet margin (Chandler et al., 2013; Bartholomew et al., 2011). Runoff increased over the past decade, with an anomalously high melting in 2010 (Van As et al., 2012), which would likely increase subglacial discharge and promote expansion of efficient drainage, potentially triggering drainage of the reservoir.

Without detailed ice thickness and bed information, or maximum rates of surface lowering, it is not clear whether collapse of the lake and formation of the depression occurred through brittle or ductile deformation of the surrounding ice. Sudden drainage of a supraglacial lake resulted in uplift of a $750 \mathrm{~m}$ wide column of ice through faulting of the full $\sim 1 \mathrm{~km}$ ice thickness (Das et al., 2008). Rapid drainage of a subglacial lake may provide the inverse situation by suddenly removing the hydraulic support for the floating ice column above, resulting in shear stresses exceeding the strength of the ice and causing full-thickness faulting. Slower drainage, however, may have been accommodated through viscous creep. A constant surface lowering rate over the 14 days gives a vertical shear strain rate at the lake perimeter on the order of $10^{-7} \mathrm{~s}^{-1}$, implying shear stresses between $300 \mathrm{kPa}$, for ice near the freezing temperature, and $950 \mathrm{kPa}$ for ice at $-30^{\circ} \mathrm{C}$ (Cuffey and Paterson, 2010). Distributed around the perimeter of the lake, these shear stresses would only support between 7 and $20 \%$ of the weight of the ice above the lake, with water pressure required to support the remainder. This surface-lowering rate is therefore also consistent with a catastrophic drainage, in which the water pressure dropped substantially as soon as outflow began.

While the 2013 DEM shows shallowing of the depression (Fig. 3), it is uncertain whether this is due to subglacial refilling of the lake or infilling of the surface depression by meltwater, blowing snow and ice talus from the collapse of the surrounding crevasses. If overfilling and pressurization of the reservoir forced rapid drainage into a surrounding, inefficient drainage system we would expect the reservoir to refill as the drainage tunnels collapse. If, however, drainage was triggered by the inland propagation of an efficient drainage system, the persistence of that regime may prevent refilling of the lake. Thus, failure of the lake to refill may signal a more permanent shift in the ice sheet's subglacial drainage system.

\section{Conclusions}

We have provided the first direct evidence of long-term storage and sudden release of meltwater within a lake beneath the Greenland Ice Sheet. The lake existed in the upper ablation zone where it likely had received relatively low and intermittent discharges of surface meltwater through englacial conduits, preventing efficient drainage, in an area of reversed surface slope that likely created a reversal in the hydraulic gradient. Drainage of the lake may have been triggered by increasing efficiency of the subglacial drainage system with increased meltwater inputs under recent warming. By itself, the volume of the lake is insignificant to the hydrologic budget of the ice margin, equivalent to 1 year of runoff over a $20 \mathrm{~km}^{2}$ area at the elevation of the depression. However, there is no indication that this feature should be unique. Undulating surface topography with similar slope reversals is common over the upper ablation zone of the margin. Before drainage there is very little surface expression to identify the presence of a lake. Its small size and the abundance of water at the bed reduces the likelihood of detection of undrained lakes with airborne ice-penetrating radar. Nothing anomalous exists in the radar echogram from the 1993 survey over the eastern portion of the lake. Even after drainage and surface collapse, the abundance of drained supraglacial lake basins and other features makes the depression difficult to identify in commonly available satellite imagery. Finally, the depression infills with snow quickly after the collapse, limiting the time in which it could be detected to a few years. Collection of detailed bed topography and ice thickness in the vicinity of the depression would provide insight into the conditions that caused the lake to form and, potentially, drain. We would then be able to assess the likelihood that other lakes exist and where they may be found. 


\section{Appendix A: Data set descriptions}

Orthorectified Landsat imagery was obtained from the United States Geological Survey Earth Explorer archive (http://earthexplorer.usgs.gov/). These data are radiometrically calibrated and corrected for terrain distortions using a DEM prior to distribution (http://landsat.usgs.gov/Landsat_ Processing_Details.php).

WorldView stereopair images were obtained from the Polar Geospatial Center at the University of Minnesota. We used the Ohio State University DEM extraction software Surface Extraction through TIN-Based Minimization (SETSM, http://www.pgc.umn.edu/system/files/ SETSM_Product_Sheet_v1.1.pdf) to construct the DEM and generate the orthoimages. The DEMs were coregistered to lidar data collected by NASA's Operation IceBridge in March and April of 2011 and 2013. Following coregistration, vertical errors in the DEM are less than $0.5 \mathrm{~m}$.
We obtained the ATM Level 1B and Kansas University Multichannel Coherent Radar Depth Sounder ice-penetrating radar data from the National Snow and Ice Data Center (http: //nsidc.org/data/icebridge/). We use the ICESat 633 products of the GLA12 release corrected for time-varying elevation biases and filtered as described in Shepherd et al. (2012). Elevations were corrected for detector saturation, and the time-varying bias correction should remove offsets associated with campaign-to-campaign variations in the shape of the transmitted pulse (Borsa et al., 2014). Elevations calculated in this way should be accurate to better than $0.1 \mathrm{~m}$. 
Author contributions. I. M. Howat led the data compilation, analysis and writing of the paper. C. Porter first identified the surface depression and preprocessed and provided the WV imagery. M. J. Noh constructed the WV DEMs. B. E. Smith provided the ICESat data and assisted with the analysis. S. Jeong aided with Landsat imagery processing. All authors contributed to manuscript preparation.

Acknowledgements. This work was supported by grant NNX10AN61G to I. M. Howat from the US National Aeronautics and Space Administration. The authors thank the numerous instrument teams and data providers that collected and supplied the data used in this study.

Edited by: O. Gagliardini

\section{References}

Bartholomew, I., Nienow, P., Sole, A., Mair, D., Cowton, T., Palmer, S., and Wadham, J.: Supraglacial forcing of subglacial drainage in the ablation zone of the Greenland ice sheet, Geophys. Res. Lett., 38, L08502, doi:10.1029/2011GL047063, 2011.

Borsa, A. A., Moholdt, G., Fricker, H. A., and Brunt, K. M.: A range correction for ICESat and its potential impact on ice-sheet mass balance studies, The Cryosphere, 8, 345-357, doi:10.5194/tc-8345-2014, 2014.

Chandler, D. M., Wadham, J. L., Lis, G. P., Cowton, T., Sole, A., Bartholomew, I., Telling, J., Nienow, P., Bagshaw, E. B., Mair, D., Vinen, S., and Hubbard, A.: Evolution of the subglacial drainage system beneath the Greenland Ice Sheet revealed by tracers, Nature Geosci., 6, 195-198, 2013.

Clarke, G. C.: Glaciology: Ice-sheet Plumbing in Antarctica, Nature, 440, 1000-1001, doi:10.1038/4401000a, 2006.

Cuffey, K. M. and Paterson, W. S. B.: The Physics of Glaciers, 4, Butterworth-Heinemann, Amsterdam, 72-73, 2010.

Das, S. B., Joughin, I., Behn, M. D., Howat, I. M., King, M. A., Lizarralde, D., and Bhatia, M. P.: Fracture propagation to the base of the Greenland Ice Sheet during supraglacial lake drainage, Science, 320, 778-781, doi:10.1126/science.1153360, 2008.

Fitzpatrick, A. A. W., Hubbard, A., Joughin, I., Quincey, D. J., Van As, D., Mikkelsen, A. P. B., Doyle, S. H., Hasholt, B., and Jones, G. A.: Ice flow dynamics and surface meltwater flux at a landterminating sector of the Greenland ice sheet, J. Glaciol., 59, 687-696, doi:10.3189/2013JoG12J143, 2013.

Fitzpatrick, A. A. W., Hubbard, A. L., Box, J. E., Quincey, D. J., van As, D., Mikkelsen, A. P. B., Doyle, S. H., Dow, C. F., Hasholt, B., and Jones, G. A.: A decade (2002-2012) of supraglacial lake volume estimates across Russell Glacier, West Greenland, The Cryosphere, 8, 107-121, doi:10.5194/tc-8-107-2014, 2014.

Forster, R. R., Box, J. E., van den Broeke, M. R., Miege, C., Burgess, E. W., van Angelen, J. H., Lenaerts, J. T. M., Koenig, L. S., Paden, J., Lewis, C., Gogineni, S. P., Leuschen, C., and McConnell, J. R.: Extensive liquid meltwater storage in firn within the Greenland ice sheet, Nature Geosci., 7, 95-98, doi:10.1038/NGEO2043, 2014.
Gray, L., Joughin, I., Tulaczyk, S., Spikes, V.B., Bindschadler, R., and Jezek, K.: Evidence for subglacial water transport in the West Antarctic Ice Sheet through three-dimensional satellite radar interferometry, Geophys. Res. Lett., 32, L03501, doi:10.1029/2004GL021387, 2005.

Joughin, I., Smith, B. E., Howat, I. M., Scambos, T., and Moon, T.: Greenland flow variability from ice-sheet-wide velocity mapping, J. Glaciol., 56, 415-430, 2010.

Joughin, I., Das, S. B., Flowers, G. E., Behn, M. D., Alley, R. B., King, M. A., Smith, B. E., Bamber, J. L., van den Broeke, M. R., and van Angelen, J. H.: Influence of ice-sheet geometry and supraglacial lakes on seasonal ice-flow variability, The Cryosphere, 7, 1185-1192, doi:10.5194/tc-7-1185-2013, 2013.

Korona, J., Berthier, E., Bernard, M., Rémy, F., and Thouvenot, E.: SPIRIT. SPOT 5 stereoscopic survey of Polar Ice: Reference Images and Topographies during the fourth International Polar Year (2007-2009), ISPRS J. Photogramm., 64, 204-212, doi:10.1016/j.isprsjprs.2008.10.005, 2009.

Palmer, S. J., Dowdeswell, J. A., Christoffersen, P., Young, D. A., Blankenship, D. D., Greenbaum, J. S., Benham, T., Bamber, J., and Siegert, M. J.: Greenland subglacial lakes detected by radar, Geophys. Res. Lett., 40, 6154-6159, doi:10.1002/2013GL058383, 2013.

Schoof, C.: Ice-sheet acceleration driven by melt supply variability, Nature, 468, 803-806, doi:10.1038/nature09618, 2010.

Shepherd, A., Ivins, E. R., Geruo, A., Barletta, V. R., Bentley, M. J., Bettadpur, S., Briggs, K. H., Bromwich, D. H., Forsberg, R., Galin, N., Horwath, M., Jacobs, S., Joughin, I., King, M. A., Lenaerts, J. T. M., Li, J. L., Ligtenberg, S. R. M., Luckman, A., Luthcke, S. B., McMillan, M., Meister, R., Milne, G., Mouginot, J., Muir, A., Nicolas, J. P., Paden, J., Payne, A. J., Pritchard, H., Rignot, E., Rott, H., Sorensen, L. S., Scambos, T. A., Scheuchl, B., Schrama, E. J. O., Smith, B., Sundal, A. V., van Angelen, J. H., van de Berg, W. J., van den Broeke, M. R., Vaughan, D. G., Velicogna, I., Wahr, J., Whitehouse, P. L., Wingham, D. J., Yi, D. H., Young, D., and Zwally, H. J.: A Reconciled Estimate of Ice-Sheet Mass Balance, Science, 338, 1183-1189, doi:10.1126/science.1228102, 2012.

van As, D., Hubbard, A. L., Hasholt, B., Mikkelsen, A. B., van den Broeke, M. R., and Fausto, R. S.: Large surface meltwater discharge from the Kangerlussuaq sector of the Greenland ice sheet during the record-warm year 2010 explained by detailed energy balance observations, The Cryosphere, 6, 199-209, doi:10.5194/tc-6-199-2012, 2012.

Wingham, D. J., Siegert, M. J., Shepherd, A., and Muir, A. S.: Rapid discharge connects Antarctic subglacial lakes, Nature, 440, 1033-1036, 2006. 